\title{
Large-scale patterns of dynamics in subtidal macrozoobenthic assemblages in the Skagerrak: effects of a production-related factor?
}

\author{
A. B. Josefson \\ National Swedish Environment Protection Board, Coastal Water Section, Kristineberg Marine Biological Station, \\ S-45034 Fiskebäckskil, Sweden
}

\begin{abstract}
Macrobenthic infauna at water depths between 10 and $300 \mathrm{~m}$ was monitored over 5 yr in an $80 \mathrm{~km}$ wide area of the Swedish west coast. Year-to-year variations in number of individuals were analysed for total fauna, trophic and reproductive groups and dominating species. Results demonstrated significant variations in total abundance synchronised between stations suggesting the importance of some extrinsic factor. Relative positions of dominants seemed largely unaltered, suggesting a similar response among species to the common factor. Much of the variability was accounted for by short-lived predatory and surface-deposit-feeding polychaetes and surface-deposit-feeding cumaceans. A comparison of the variability between species with planktotrophic and lecithotrophic larval development showed no difference between the categories, suggesting that the common factor operated on the bottom. Temperature and salinity data suggest only small differences between years. It is argued that the major cause of the common variability pattern is a factor related to production in the sea such as sedimentation of organic matter, which affects either of, or a combination of, settlement, somatic growth and survival on the bottom. Sediment organic matter over 3 yr changed in a way that would be predicted from the faunal changes and consistent with the hypothesis that sedimentation had caused the variation. Increased abundances were accompanied by increased organic content.
\end{abstract}

\section{INTRODUCTION}

An important question in ecology is the relative importance of extrinsic versus intrinsic factors in inducing variability and producing structure in animal communities. Extrinsic factors are often, though not always, physical or chemical in nature, while intrinsic ones often are biological. In the marine environment deepwater communities are thought to be largely affected by biological factors (according to e.g. the stability-time hypothesis; Sanders 1968), while physico-chemical ones are of greater importance in shallow water (e.g. effects of warm and cold winters in boreal areas; Ziegelmeier 1964, 1978, Beukema et al. 1978).

One way to assess the importance of physico-chemical factors is to study temporal variability in abundance or biomasses on a large scale. Effects of factors such as biological interactions are less likely to be similar over large areas than physical ones because proportions of dominants and potential predators often vary locally.
Further, through study of variability over a great range of water depths the number of factors that can cause a common pattern are considerably reduced. For example, in the present area - the Skagerrak - storms, extreme temperatures and the like are not likely to significantly affect bottoms deeper than say $50 \mathrm{~m}$. Factors that are likely to have similar effects over a great bathymetrical range are sedimentation of organic matter and temperature effects on growth and reproduction. While some long-term studies of multi-species assemblages now exist from single stations or a few localities (e.g. Coull 1985, Coull \& Dudley 1985 on meiofauna; Buchanan \& Moore 1986, Buchanan et al. 1986, Josefson 1986a on macrofauna), few such largescale studies have been published (but see Ziegelmeier 1963, 1964, 1978, Andersin et al. 1978, Stull et al. 1986).

In this paper I examine patterns of temporal variability of macrobenthos abundance over 5 yr at 6 to 12 stations in the Skagerrak. The stations cover an area $80 \mathrm{~km}$ wide and water depths from 10 to $300 \mathrm{~m}$ (Fig. 1 . 
Table 1). Data on temporal variability from 3 of these stations from the 1970 s have been published elsewhere (Josefson 1981, 1982, 1986a, Josefson \& Smith 1984). Apart from the latter authors who mainly considered changes in total biomass during 1970-1982, this paper is the first one considering variability in the area as such, rather than at a few local sites. If large-scale factors are important, I expect synchronisation of the local inter-annual patterns between stations. The interannual variability is analysed in terms of functional and taxonomic groups, and species are identified which account for a major part of the variability within the groups. I present evidence that large-scale factors do induce variation in abundances of the total and functional groups, and discuss possible underlying causes for this variability.

\section{MATERIAL AND METHODS}

Programme and investigated sites. The present data have been abstracted from a monitoring programme aiming at providing a base line for surveillance of the waters along the Swedish west coast. The stations visited once a year are considered here (Fig. 1, Table 1). The time series consist of samples taken every year in May 1981 to 1985. Full series are available from 6 of the 12 stations in the depth interval 30 to $300 \mathrm{~m}$ (Stns 7 to 12 in Table 1, Fig. 1), whereas data exist from all 12 stations for the period 1983 to 1985. Seven of the stations are situated in sheltered inshore areas close to and in the Gullmar fjord, while 5 are in the open sea. All stations, except that at $300 \mathrm{~m}$, are overflown by the Baltic Current and, except for the one at $10 \mathrm{~m}$ depth, influenced by so-called Skagerrak water which is partly of North Sea origin. Thus most stations are basically affected by the same water masses. For further details on the hydrography in the area see Svansson (1975).

Six of the stations, mainly the offshore ones, are situated in areas where bottom trawling is permitted and 6 in areas where this is not permitted. All stations except that in the Gullmar fjord basin are situated in well-flushed areas. No station is known to be affected by any single pollution souce.

Hydrographical characterization of the period 1981-1985. Nearly monthly measurements of temperature and salinity were made during the investigation period in the middle of the Gullmar fjord (Fishery Board of Sweden, Odd Lindahl pers. comm.). Data from $40 \mathrm{~m}$ depth showed no large differences in these 2 factors among the years 1980 to 1984 (Fig. 2). The temperature sum at $40 \mathrm{~m}$ (in day degrees) was only $10 \%$ lower in the coldest year (1983) compared with the warmest year (1980).

Methods. At each station and date a sample of 5

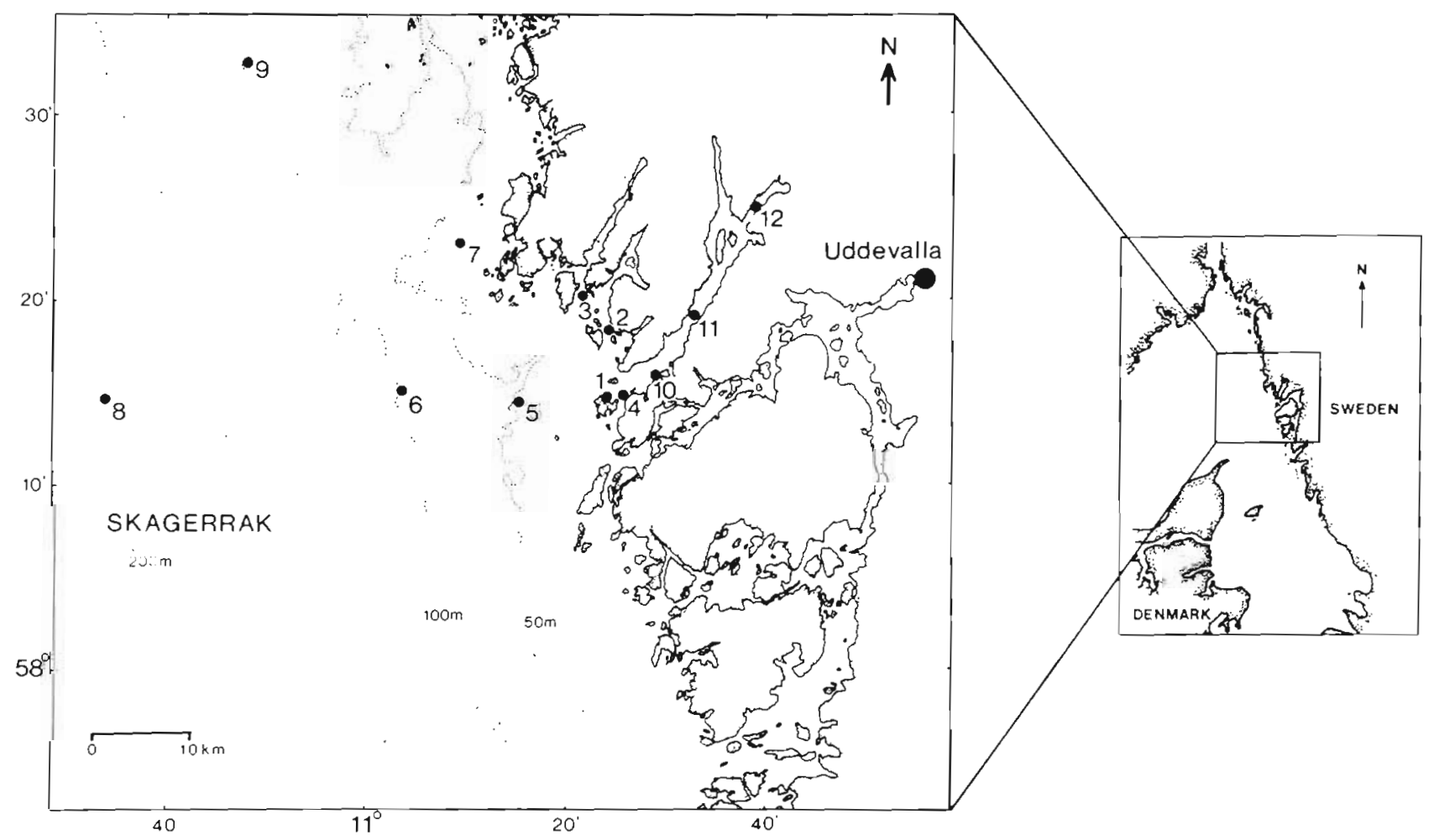

Fig. 1. Map showing study area with sampling stations. All stations were monitored $1983-85$ and Stn 7 to 12 also in $1981-82$ 
Table 1. Station list showing location positions, water depths and ranges of water contents and losses on ignition of organic matter in the sediments. Sediment variables are based on data from 1983-85

\begin{tabular}{|c|c|c|c|c|c|}
\hline \multirow[t]{2}{*}{ Stn } & \multicolumn{2}{|c|}{ Position } & \multirow[t]{2}{*}{ Depth $(\mathrm{m})$} & \multirow[t]{2}{*}{ Water content $(\%)$} & \multirow[t]{2}{*}{ Loss on ignition $(\%)$} \\
\hline & Long. E & Lat. N & & & \\
\hline 1 & $11>23.7$ & $58>14.8$ & 10 & $28.5-38.6$ & $1.27-4.16$ \\
\hline 2 & $11>24.0$ & $58>18.4$ & 18 & $64.1-66.7$ & $6.00-8.77$ \\
\hline 3 & $11>21.6$ & $58>20.3$ & 27 & $68.4-72.5$ & $9.12-11.76$ \\
\hline 4 & $11>25.8$ & $58>14.7$ & 40 & $60.3-69.4$ & $6.61-10.64$ \\
\hline 5 & $11>15.0$ & $58>14.4$ & 49 & $32.7-42.5$ & $1.61-3.32$ \\
\hline 6 & $11>03.5$ & $58>15.2$ & 100 & $45.5-55.3$ & $3.61-7.48$ \\
\hline 7 & $11>09.3$ & $58>23.0$ & 49 & $35.0-48.4$ & $2.09-3.85$ \\
\hline 8 & $10>34.3$ & $58>14.9$ & 300 & $64.9-71.1$ & $6.03-12.63$ \\
\hline 9 & $10>47.5$ & $58>32.5$ & 100 & $53.4-62.9$ & $6.02-9.28$ \\
\hline 10 & $11>28.7$ & $58>15.8$ & 30 & $50.9-58.7$ & $4.98-6.70$ \\
\hline 11 & $11>32.8$ & $58>19.2$ & 115 & $72.2-77.1$ & $8.44-12.29$ \\
\hline 12 & $11>39.0$ & $58>25.0$ & 44 & $67.1-73.6$ & $7.79-11.72$ \\
\hline
\end{tabular}
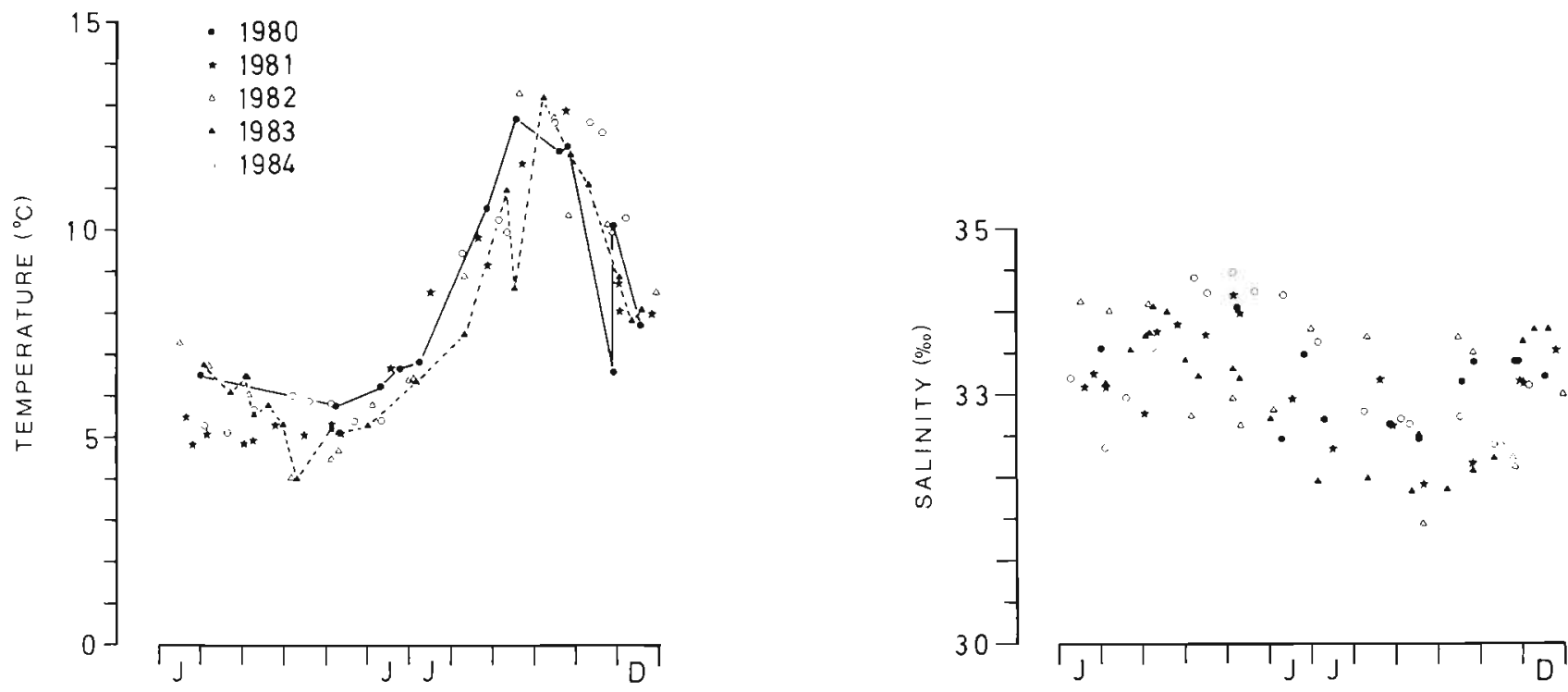

Fig. 2. Variations in temperature and salinity at $40 \mathrm{~m}$ depth in the Gullmar fjord during the 5 yr 1980-84. The warmest year (1980) is indicated by a solid line, and the coldest year (1983) by a broken line

replicate grabs were taken with a modified SmithMcIntyre grab (making up a total of 240 grabs). The grabs, each covering a bottom area of $0.1 \mathrm{~m}^{2}$ and taking a sediment volume of 15.5 l when full, were sieved through a $1 \mathrm{~mm}$ screen and preserved in $4 \%$ buffered formalin. Grab samples were resieved at the laboratory and split into 2 size fractions: 1 to $2 \mathrm{~mm}$ and $>2 \mathrm{~mm}$. The former fraction was sorted using a stereo-microscope and the latter using a magnifying lamp. Animals of the 4 major groups Polychaeta, Mollusca, Echinodermata and Crustacea were determined to species level when possible. For further details on sampling and sorting see Josefson (1981).

Water content in the sediment was determined as wet weight minus dry weight obtained through drying to constant weight at $80^{\circ} \mathrm{C}$. Loss on ignition was obtained through burning for $5 \mathrm{~h}$ in a muffe furnace at $500{ }^{\circ} \mathrm{C}$. Both variables were measured from duplicate sub-cores in a core taken with a Jonasson-Olausson box sampler. The fauna was not removed prior to analysis.

Material. The present analysis is based on more than 500 taxa occurring in the area. The species were classified into functional groups based on their feeding and reproduction, as well as into major taxonomic groups.

The feeding categories chosen were surface-deposit feeders, suspension feeders, subsurface-deposit feeders and predatory/omnivorous feeders. Reproductive categories were planktotrophic species which have lar- 
vae with long pelagic life that depend on food from plankton, and lecithotrophic species which have larvae with a short pelagic stage that depend primarily on yolk. The classifications into functional groups were based on information from both the literature and my own observations (see also Josefson 1985, 1986a).

Within each category, dominating species were selected for further analysis as follows. First the 5 top ranked species (in terms of abundance) within a category in any of the 48 samples were selected. These constituted on average $81 \%$ of a sample for surfacedeposit feeders, $96 \%$ for suspension feeders, $88 \%$ for subsurface-deposit feeders and $76 \%$ for predatory species. Of these species the ones occurring among the 5 dominants in more than 10 samples were selected for further analysis of temporal variability. The tests of concordance (below) between species rank-orders, however, were made on all species from the actual station belonging to the top 5 dominants.

Statistical tests. Changes in abundances of individual species and sediment variables were tested with a 2-way ANOVA with replication ( $\mathrm{n}=5$ for the faunal data and $\mathrm{n}=2$ for the sediment data) (SAS Institute 1982) where one factor was time (yr) and the other factor depth $(\mathrm{m})$. Since the variances for the abundances in many cases were significantly unequal (Hartley's Fmax-test, Sokal \& Rohlf 1981, p. 403) data were transformed using ln $(x+1)$. The data on ignition loss and water content were arcsin transformed $(\arcsin \sqrt{x})$. Differences between individual means were tested with the Student-Newman-Keuls procedure (Sokal \& Rohlf 1969). No interaction was assumed between time and depth. Kendall's W (Siegel 1956, p. 229) was used to test for concordance between species rank-orders in terms of density with time at single stations, and the rank-orders of densities in years over stations. The use of this statistic as a measure of community structure has previously been used by for example Grossmann et al. (1982). They pointed out the increased risk of Type I errors using this test, that is the risk of rejecting a true null hypothesis. As the test is based on ranks, rare species will contribute as much as dominating ones, thus a significant correlation may occur despite large fluctuations among top dominants. However, this prob-

Table 2. Investigation area means of number of individuals per $0.1 \mathrm{~m}^{2}$ for functional groups in May 1981-85. Values from 1981 and 82 are based on 6 stations, values from the other years are based on 12 stations. Sign = level of significance for the effect of time using a 2-way ANOVA: $\cdots p<0.001$. Commonly underlined years are not significantly different $(p>0.05$, Student Newman Keuls test)

\begin{tabular}{|c|c|c|c|c|c|c|}
\hline \multirow{2}{*}{$\frac{\text { Category }}{\text { Total density }}$} & \multirow{2}{*}{$\frac{\operatorname{Sign}}{\ldots}$} & \multicolumn{5}{|c|}{ Year (No. of individuals) } \\
\hline & & $\begin{array}{l}1983 \\
(526)\end{array}$ & $\begin{array}{l}1985 \\
(337)\end{array}$ & $\begin{array}{l}1981 \\
(321)\end{array}$ & $\begin{array}{l}1982 \\
(270)\end{array}$ & $\begin{array}{l}1984 \\
(285)\end{array}$ \\
\hline Polychaeta & $\cdots$ & $\begin{array}{l}1983 \\
(290) \\
\end{array}$ & $\begin{array}{r}1985 \\
(168) \\
\end{array}$ & $\begin{array}{l}1981 \\
(182)\end{array}$ & $\begin{array}{l}1982 \\
(142) \\
\end{array}$ & $\begin{array}{l}1984 \\
(128) \\
\end{array}$ \\
\hline Mollusca & $\cdots$ & $\begin{array}{l}1983 \\
(113) \\
\end{array}$ & $\begin{array}{l}1985 \\
(103) \\
\end{array}$ & $\begin{array}{c}1984 \\
(99) \\
\end{array}$ & $\begin{array}{r}1982 \\
(62) \\
\end{array}$ & $\begin{array}{r}1981 \\
(63) \\
\end{array}$ \\
\hline Echinodermata & $\cdots$ & $\begin{array}{r}1983 \\
(40) \\
\end{array}$ & $\begin{array}{r}1985 \\
(56) \\
\end{array}$ & $\begin{array}{r}1984 \\
(34) \\
\end{array}$ & $\begin{array}{r}1981 \\
(28) \\
\end{array}$ & $\begin{array}{r}1982 \\
(27) \\
\end{array}$ \\
\hline Crustacea & $\cdots$ & $\begin{array}{r}1983 \\
(65) \\
\end{array}$ & $\begin{array}{r}1982 \\
(32) \\
\end{array}$ & $\begin{array}{r}1981 \\
(33) \\
\end{array}$ & $\begin{array}{r}1984 \\
(18) \\
\end{array}$ & $\begin{array}{r}1985 \\
\quad(27) \\
\end{array}$ \\
\hline Surface-deposit & $\cdots$ & $\begin{array}{l}1983 \\
(241) \\
\end{array}$ & $\begin{array}{r}1985 \\
(114) \\
\end{array}$ & $\begin{array}{c}1982 \\
(111) \\
\end{array}$ & $\begin{array}{r}1981 \\
(119) \\
\end{array}$ & $\begin{array}{r}1984 \\
(90) \\
\end{array}$ \\
\hline Suspension & $\cdots$ & $\begin{array}{r}1983 \\
(81) \\
\end{array}$ & $\begin{array}{r}1984 \\
(69) \\
\end{array}$ & $\begin{array}{r}1981 \\
(29) \\
\end{array}$ & $\begin{array}{r}1985 \\
(67) \\
\end{array}$ & $\begin{array}{r}1982 \\
(32) \\
\end{array}$ \\
\hline Subsurface-deposit & $\cdots$ & $\begin{array}{l}1983 \\
(132) \\
\end{array}$ & $\begin{array}{l}1985 \\
(111) \\
\end{array}$ & $\begin{array}{l}1981 \\
(116) \\
\end{array}$ & $\begin{array}{c}1984 \\
(98) \\
\end{array}$ & $\begin{array}{r}1982 \\
(95) \\
\end{array}$ \\
\hline Predatory & $\cdots$ & $\begin{array}{r}1983 \\
(70) \\
\end{array}$ & $\begin{array}{r}1981 \\
(56) \\
\end{array}$ & $\begin{array}{r}1985 \\
(44) \\
\end{array}$ & $\begin{array}{r}1984 \\
\quad(29) \\
\end{array}$ & $\begin{array}{r}1982 \\
\quad(32) \\
\end{array}$ \\
\hline Lecithotrophic & $\cdots$ & $\begin{array}{l}1983 \\
(256) \\
\end{array}$ & $\begin{array}{l}1985 \\
(181) \\
\end{array}$ & $\begin{array}{l}1981 \\
(197) \\
\end{array}$ & $\begin{array}{c}1982 \\
(181) \\
\end{array}$ & $\begin{array}{r}1984 \\
(149) \\
\end{array}$ \\
\hline Planktotrophic & $\cdots$ & $\begin{array}{l}1983 \\
(249) \\
\end{array}$ & $\begin{array}{l}1985 \\
(146) \\
\end{array}$ & $\begin{array}{l}1981 \\
(107)\end{array}$ & $\begin{array}{l}1984 \\
(128) \\
\end{array}$ & $\begin{array}{r}1982 \\
(79) \\
\end{array}$ \\
\hline
\end{tabular}


lem is not likely to affect the present analysis as all species used are in fact high-ranked dominants.

\section{RESULTS}

Changes in mean abundances over the investigation area of the total, taxonomic and functional groups are summarized in Table 2. Total abundance showed a highly significant change over the area with an increase between 1982 and 1983, a decrease between 1983 and 1984, and again an increase between 1984 and 1985. Peak abundance was reached in 1983. Among taxonomic groups, polychaetes showed a similar pattern with a significant difference also between 1981 and 1982. Molluscs showed significantly higher abundance in 1983. Echinoderms showed a significant increase between 1982 and 1983 and seemed to show a net increase over the period. Crustaceans showed a pattern similar to the total abundance.

Among trophic groups, surface-deposit feeders showed a pattern similar to Polychaeta and the total, and so did predatory species which changed significantly between all 5 years. Subsurface-deposit feeders showed a peak in 1983 and high abundance also in 1985. Suspension feeders showed a peak in 1983. The changes in abundance of the different trophic groups at the six 5 yr stations are shown in Fig. 3.

The 2 reproductive categories showed identical patterns with significantly higher values in 1983 and 1985. The changes in abundance of reproductive groups at the six 5 yr stations are shown in Fig. 4 . The

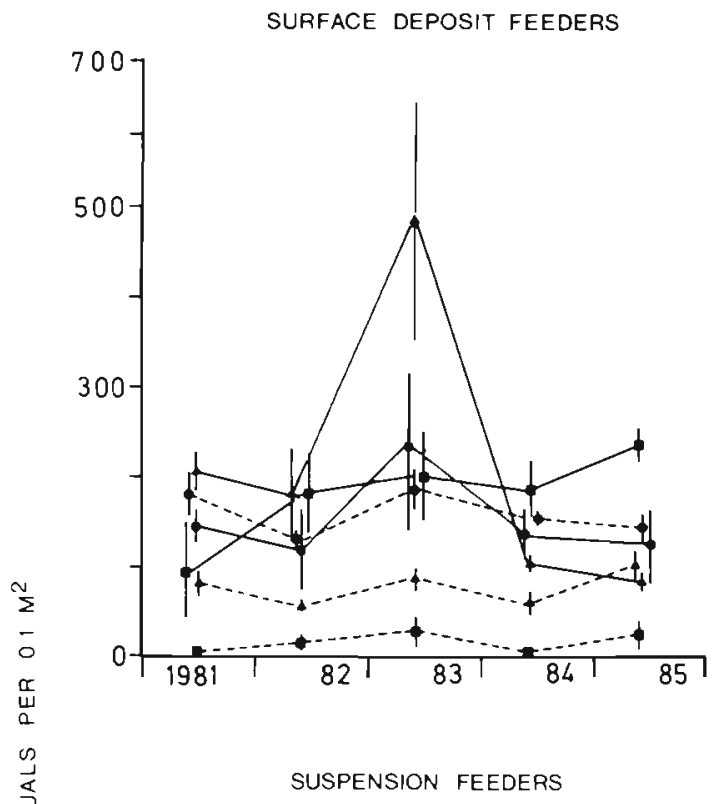

SUBSURFACE DEPOSIT FEEDERS
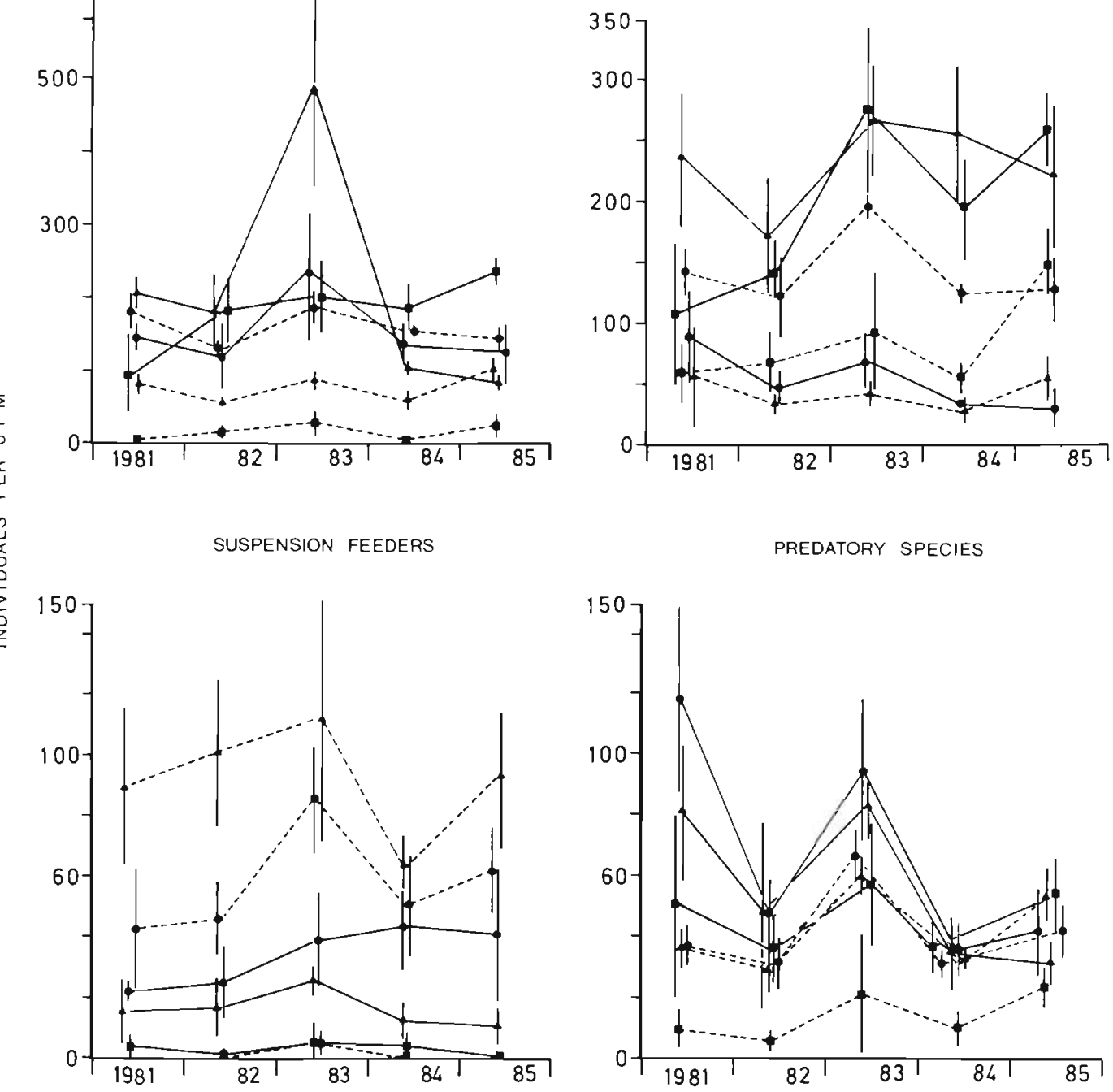

Fig. 3. Variations in density of trophic groups at the 6 stations monitored yearly between 1981-85 (•— Stn 7 ; Stn 8

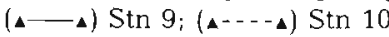


data in Table 2 and Fig. 3 \& 4 thus show that considerable changes took place during 1981 to 85 which are consistent between stations. The clearest patterns are shown by predatory and surface-deposit-feeding polychaetes.

To further test if patterns of co-variation occurred between stations, the years were ranked by abundance and the concordance between rankings tested with Kendall's W. A significant result would suggest that more or less the same pattern occurs at all stations. The results are shown for the six 5 yr stations in Table 3 . Total density, Polychaeta, surface-deposit feeders and suspension feeders show significant correlations between stations, and predators show highly significant correlations. Planktotrophic species show highly significant and lecithotrophic significant correlations between stations.

To evaluate if the variations in totals and groups were accompanied by changes in the relative positions of species within the trophic groups, the species rank-

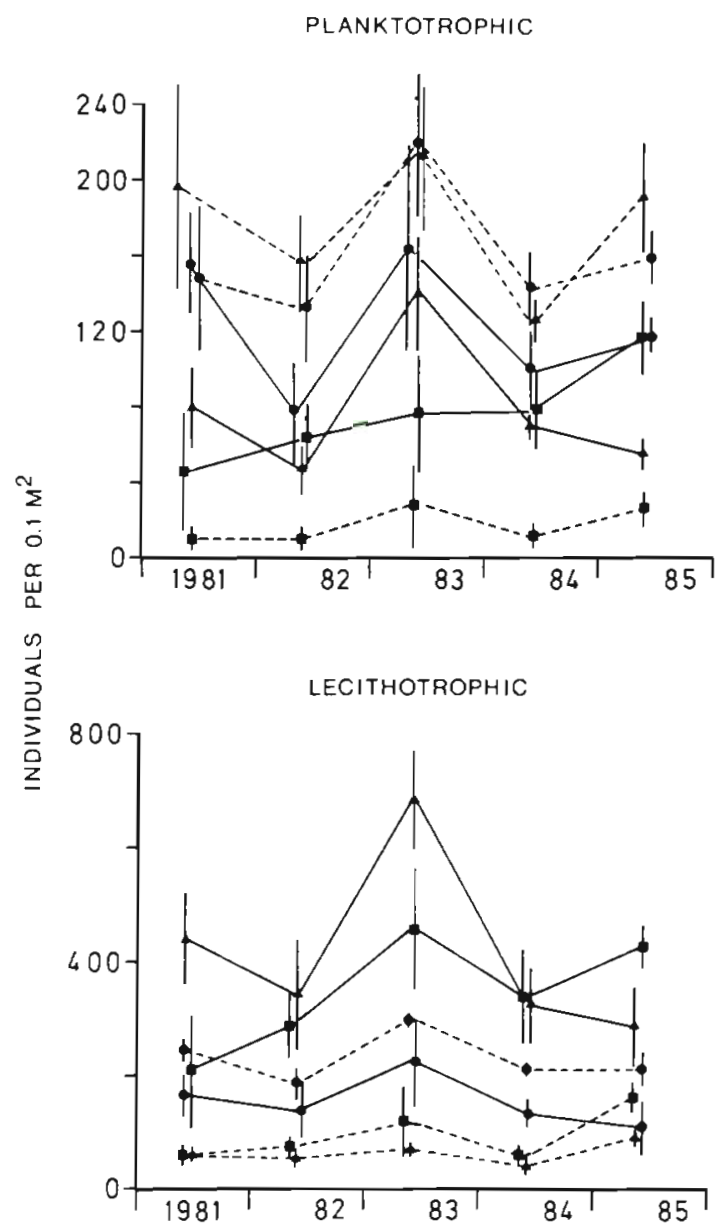

Fig. 4. Variations in density of groups with different larval development at the 6 stations monitored yearly between 1981-85. See Fig. 3 for explanation of symbols orders were tested for concordance with Kendall's W The results for the six 5 yr stations are shown in Table 4.

Significant or highly significant concordance was shown by all combinations of stations and categories except in 3 cases, suggesting a high stability of the relative positions within trophic groups. One exception is surface-deposit feeders at the $115 \mathrm{~m}$ station (Stn 11) in the Gullmar fjord basin. This site, however, is periodically affected by low oxygen levels. In winter 1979/80 this site became azoic due to oxygen deficiency, and since then a recolonization took place. Low oxygen levels also occurred here in later years. It is known that surface feeders are more sensitive to such conditions than burrowing species (Gaston 1985). The 2 other exceptions are suspension feeders at 2 of the deepest stations (Stns $8 \& 9$ ). This trophic category is however poorly represented and its species occur in low to very low densities. It is well known that the presence of rare species in a sample to a large extent may be a stochastic process, and lack of correlations in such assemblages is therefore not surprising.

The species which were numerically most important within each trophic category were identified and are listed in Table 5 together with data on life history, occurrence in the samples and results of testing for temporal change. A 2-way ANOVA was used to identify those species which significantly contributed to the changes in total and groups. The mean abundances over the area and the results of testing with the Student-Newman-Keuls procedure are shown in Table 6 for each of the dominating species.

Among surface-deposit feeders the bivalve Abra nitida, the polychaetes Prionospio malmgreni and Chaetozone setosa and the cumaceans Diastylis lucifera and Leucon nasica showed highly significant

Table 3. Statistical test of co-variation of faunal density among 6 stations during the period May 1981 to May 1985 for the total fauna and different functional groups. $W$ is the test-parameter in Kendall's rank of concordance. Sign = level of significance: $\cdots p<0.01 ; \cdot p<0.05 ;$ ns: $p>0.05$

\begin{tabular}{|lrrl|}
\hline Category & W & $\begin{array}{c}\text { Chi- } \\
\text { square }\end{array}$ & Sign \\
\hline Total density & 0.450 & 10.80 &. \\
Polychaeta & 0.550 & 13.20 &. \\
Mollusca & 0.239 & 5.73 & ns \\
Echinodermata & 0.257 & 6.17 & ns \\
Crustacea & 0.288 & 6.90 & ns \\
Surface-deposit feeders & 0.472 & 11.33 &. \\
Suspension feeders & 0.442 & 10.60 & $\cdot$ \\
Subsurface-deposit feeders & 0.361 & 8.67 & ns \\
Predatory species & 0.578 & 13.87 &.$\cdot$ \\
Planktotrophic & 0.606 & 14.53 &.. \\
Lecitotrophic & 0.440 & 10.57 &. \\
\hline
\end{tabular}


Table 4. Tests of concordance between dominant species rankings for the 5 yr 1981-85 at 6 stations. Dominant species are those occuring among the 5 top ranked ones of a category in at least one sample. Sign $=$ level of significance using Kendall's rank of concordance test; $\mathrm{N}$ : number of species. ${ }^{\prime} \mathrm{p}<0.05 ;{ }^{\cdots} \mathrm{p}<0.01 ; \cdots p<0.001 ; \mathrm{ns}$ : $\mathrm{p}>0.05$

\begin{tabular}{|c|c|c|c|c|c|c|c|c|}
\hline \multirow[t]{2}{*}{ Stn } & \multicolumn{2}{|c|}{ Surface-deposit } & \multicolumn{2}{|c|}{ Suspension } & \multicolumn{2}{|c|}{ Subsurface-deposit } & \multicolumn{2}{|c|}{ Predatory } \\
\hline & $\mathrm{N}$ & Sign & N & Sign & $\mathrm{N}$ & Sign & $\mathrm{N}$ & Sign \\
\hline 12 & 9 & $\cdots$ & 9 & $\cdots$ & 6 & $\cdots$ & 7 & $\cdots$ \\
\hline 11 & 16 & ns & - & - & 9 & $\cdots$ & 11 & $\cdots$ \\
\hline 10 & 8 & $\cdots$ & 9 & $\cdots$ & 9 & $\cdots$ & 7 & $\cdots$ \\
\hline 7 & 8 & $\cdot$ & 8 & $\cdots$ & 9 & $\cdots$ & 9 & $\cdots$ \\
\hline 8 & 7 & $\cdots$ & 13 & ns & 7 & $\cdots$ & 9 & $\cdots$ \\
\hline 9 & 11 & $\cdots$ & 11 & ns & 8 & $\cdot$ & 8 & $\because$ \\
\hline
\end{tabular}

Table 5. Lists of dominating species within feeding categories. Included are those ranked in the top 5 of a category in at least 10 of all 48 samples. Indicated for each species are taxonomic group (Tax. group), type of larval development (Dev.), approximate life span, percent occurrence in the samples (Ocur.), highest density in 1983, and results of statistical testing for temporal change (ANOVA), where $p$ is the probability of no change and 'sign' the level of significance $(\cdots p<0.001 ; \cdots p<0.01 ; \cdot p<0.05 ; n s$ : p>0.05). Mo: Mollusca; Po: Polychaeta; Cr: Crustacea; Ec: Echinodermata; Pl: planktotrophic larval development; Le: lecithotrophic larval development

\begin{tabular}{|c|c|c|c|c|c|c|c|}
\hline \multirow[t]{2}{*}{ Species } & \multirow{2}{*}{$\begin{array}{l}\text { Tax. } \\
\text { group }\end{array}$} & \multirow[t]{2}{*}{ Dev. } & \multirow{2}{*}{$\begin{array}{l}\text { Life span } \\
\quad(y r)\end{array}$} & \multirow{2}{*}{$\begin{array}{c}\text { Ocur. } \\
\%\end{array}$} & \multirow{2}{*}{$\begin{array}{c}\text { Peak in } \\
1983\end{array}$} & \multicolumn{2}{|c|}{ ANOVA } \\
\hline & & & & & & $\mathrm{p}$ & $\operatorname{sign}$ \\
\hline \multicolumn{8}{|l|}{ Surface-deposit feeders } \\
\hline Abra nitida & Mo & $\mathrm{Pl}$ & $2-7$ & 60 & & 0.0001 & $\cdots$ \\
\hline Prionospio malmgreni & Po & $\mathrm{Pl}$ & $<2$ & 50 & Yes & 0.0001 & $\cdots$ \\
\hline Diplocirrus glaucus & Po & Le & $>1$ & 50 & Yes & 0.0016 & $\cdots$ \\
\hline Diastylis lucifera & $\mathrm{Cr}$ & Le & $<1$ & 38 & Yes & 0.0001 & $\cdots$ \\
\hline Amphiura chiajei & $\mathrm{Ec}$ & $\mathrm{Pl}$ & $>4$ & 38 & & 0.8248 & ns \\
\hline Chaetozone setosa & Po & Le & $1-2$ & 31 & Yes & 0.0001 & $\cdots$ \\
\hline Sosane gracilis & Po & Le & 2 & 29 & Yes & 0.0014 & $\cdots$ \\
\hline Leucon nasica & $\mathrm{Cr}$ & Le & $<1$ & 27 & Yes & 0.0001 & $\cdots$ \\
\hline \multicolumn{8}{|l|}{ Suspension feeders } \\
\hline Mysella bidentata & Mo & $\mathrm{Pl}$ & $3-6$ & 81 & & 0.2228 & ns \\
\hline Amphiura filiformis & $\mathrm{EC}$ & $\mathrm{Pl}$ & $>4$ & 75 & Yes & 0.0001 & $\cdots$ \\
\hline Montacuta tenella & Mo & $\mathrm{Pl}$ & ? & 46 & & 0.7863 & ns \\
\hline Corbula gibba & Mo & $\mathrm{Pl}$ & ? & 35 & Yes & 0.0001 & $\cdots$ \\
\hline Phoronis muelleri & & $\mathrm{Pl}$ & $i$ & 31 & & 0.0157 & $\cdot$ \\
\hline \multicolumn{8}{|l|}{ Subsurface-deposit feeders } \\
\hline Heteromastus filiformis & Po & Le & $2-3$ & 85 & Yes & 0.0001 & $\cdots$ \\
\hline Scalibregma inflatum & Po & Le & 2 & 52 & & 0.0001 & $\cdots$ \\
\hline Onoba vitrea & Mo & $\mathrm{Pl}$ & ? & 44 & & 0.0258 & $\cdot$ \\
\hline Paraonis gracilis & Po & Le & 2 & 40 & & 0.0001 & $\cdots$ \\
\hline Thyasira equalis & Mo & Le & 2.5 & 40 & & 0.0102 & $\cdot$ \\
\hline Thyasira sarsi & Mo & Le & 2.5 & 35 & & 0.0001 & $\cdots$ \\
\hline Rhodine loveni & Po & Le & 2 & 25 & & 0.5025 & ns \\
\hline \multicolumn{8}{|l|}{ Predatory species } \\
\hline Nemertini & & & & 90 & Yes & 0.0001 & $\cdots$ \\
\hline Pholoe minuta & Po & $\mathrm{Pl}$ & 2 & 75 & Yes & 0.0001 & 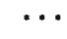 \\
\hline Glycera alba & Po & $\mathrm{Pl}$ & $>5$ & 38 & Yes & 0.0236 & $\cdot$ \\
\hline Lumbrineris sp. & Po & Le & $1-3$ & 38 & & 0.1784 & ns \\
\hline Cylichna cylindracea & Mo & $?$ & $>1$ & 35 & & 0.5259 & ns \\
\hline Goniada maculata & Po & Le & 2.5 & 33 & & 0.0049 & $\cdots$ \\
\hline Nephtys incisa & Po & $\mathrm{Pl}$ & 3 & 25 & & 0.0925 & ns \\
\hline Paramphinome jeffreysi & Po & $\mathrm{Pl}$ & 2 & 25 & & 0.0025 & ns \\
\hline
\end{tabular}

$(p<0.001)$ changes over the period 1981-85. All of them except A. nitida showed basically the same pattern with peak values in 1983 (Table 6). The polychaetes Diplocirrus glaucus and Sosane gracilis changed very significantly $(p<0.01)$, whereas the ophiuroid Amphiura chiajei did not change ( $p>0.05)$. 
Table 6. Average yearly densities for 28 dominating species from 6 stations (see text) and results of testing for differences between years with the Student-Newman-Keuls test. Commonly underlined years are not significantly different $(p>0.05)$

\begin{tabular}{|c|c|c|c|c|c|c|c|c|c|c|c|}
\hline \multirow{2}{*}{$\frac{\text { Taxon }}{\text { Abra nitida }}$} & \multicolumn{5}{|c|}{ Year (No. of individuals per $\mathrm{m}^{2}$ ) } & \multirow{2}{*}{$\begin{array}{l}\text { Taxon } \\
\begin{array}{l}\text { Scalibregma } \\
\text { inflatum }\end{array}\end{array}$} & \multicolumn{5}{|c|}{ Year (No. of indjviduals per $\mathrm{m}^{2}$ ) } \\
\hline & $\begin{array}{l}1985 \\
(307) \\
\end{array}$ & $\begin{array}{l}1984 \\
(216) \\
\end{array}$ & $\begin{array}{l}1983 \\
(214)\end{array}$ & $\begin{array}{l}1981 \\
(179)\end{array}$ & $\begin{array}{l}1982 \\
(157) \\
\end{array}$ & & $\begin{array}{r}1981 \\
(51)\end{array}$ & $\begin{array}{r}1982 \\
(47)\end{array}$ & $\begin{array}{r}1983 \\
(45) \\
\end{array}$ & $\begin{array}{r}1985 \\
(41)\end{array}$ & $\begin{array}{r}1984 \\
\quad(7) \\
\end{array}$ \\
\hline $\begin{array}{l}\text { Prionospio } \\
\text { malmgreni }\end{array}$ & $\begin{array}{l}1983 \\
(173) \\
\end{array}$ & $\begin{array}{r}1981 \\
(99) \\
\end{array}$ & $\begin{array}{r}1985 \\
(46) \\
\end{array}$ & $\begin{array}{r}1982 \\
(20) \\
\end{array}$ & $\begin{array}{r}1984 \\
(11)\end{array}$ & Onoba vitrea & $\begin{array}{r}1983 \\
(52) \\
\end{array}$ & $\begin{array}{r}1981 \\
(59) \\
\end{array}$ & $\begin{array}{r}1985 \\
(30)\end{array}$ & $\begin{array}{r}1984 \\
(22)\end{array}$ & $\begin{array}{r}1982 \\
(15)\end{array}$ \\
\hline Diplocirrus glaucus & $\begin{array}{l}1985 \\
(149) \\
\end{array}$ & $\begin{array}{l}1983 \\
(159) \\
\end{array}$ & $\begin{array}{l}1984 \\
(130)\end{array}$ & $\begin{array}{l}1982 \\
(122)\end{array}$ & $\begin{array}{r}1981 \\
(69)\end{array}$ & Paraonis gracilis & $\begin{array}{r}1981 \\
(67) \\
\end{array}$ & $\begin{array}{r}1983 \\
(47) \\
\end{array}$ & $\begin{array}{r}1985 \\
(19) \\
\end{array}$ & $\begin{array}{r}1982 \\
(10) \\
\end{array}$ & $\begin{array}{r}1984 \\
(7) \\
\end{array}$ \\
\hline Diastylis lucifera & $\begin{array}{r}1983 \\
(316) \\
\end{array}$ & $\begin{array}{c}1982 \\
(139) \\
\end{array}$ & $\begin{array}{r}1984 \\
(81) \\
\end{array}$ & $\begin{array}{l}1981 \\
(106)\end{array}$ & $\begin{array}{r}1985 \\
(39) \\
\end{array}$ & Thyasira equalis & $\begin{array}{l}1981 \\
(107) \\
\end{array}$ & $\begin{array}{l}1984 \\
(132)\end{array}$ & $\begin{array}{l}1983 \\
(130) \\
\end{array}$ & $\begin{array}{l}1985 \\
(157) \\
\end{array}$ & $\begin{array}{l}1982 \\
(133)\end{array}$ \\
\hline Amphiura chiajei & $\begin{array}{l}1984 \\
(107) \\
\end{array}$ & $\begin{array}{c}1983 \\
(106)\end{array}$ & $\begin{array}{r}1985 \\
(104) \\
\end{array}$ & $\begin{array}{r}1982 \\
(85) \\
\end{array}$ & $\begin{array}{r}1981 \\
(84) \\
\end{array}$ & Thyasira sarsi & $\begin{array}{r}1985 \\
(57) \\
\end{array}$ & $\begin{array}{r}1983 \\
\quad(45) \\
\end{array}$ & $\begin{array}{r}1982 \\
(26) \\
\end{array}$ & $\begin{array}{r}1984 \\
(23) \\
\end{array}$ & $\begin{array}{r}1981 \\
(1) \\
\end{array}$ \\
\hline Chaetozone setosa & $\begin{array}{r}1983 \\
(88) \\
\end{array}$ & $\begin{array}{r}1985 \\
(45) \\
\end{array}$ & $\begin{array}{r}1981 \\
(50) \\
\end{array}$ & $\begin{array}{r}1984 \\
(44) \\
\end{array}$ & $\begin{array}{r}1982 \\
(33) \\
\end{array}$ & Rhodine loveni & $\begin{array}{r}1983 \\
(47) \\
\end{array}$ & $\begin{array}{r}1984 \\
(45) \\
\end{array}$ & $\begin{array}{r}1985 \\
(39) \\
\end{array}$ & $\begin{array}{r}1982 \\
(36) \\
\end{array}$ & $\begin{array}{r}1981 \\
\quad(34) \\
\end{array}$ \\
\hline Sosane gracilis & $\begin{array}{r}1983 \\
(59) \\
\end{array}$ & $\begin{array}{r}1982 \\
(40) \\
\end{array}$ & $\begin{array}{r}1981 \\
(34) \\
\end{array}$ & $\begin{array}{r}1985 \\
(29) \\
\end{array}$ & $\begin{array}{r}1984 \\
(27) \\
\end{array}$ & Nemertini & $\begin{array}{l}1983 \\
(136) \\
\end{array}$ & $\begin{array}{r}1981 \\
(124) \\
\end{array}$ & $\begin{array}{r}1982 \\
(55) \\
\end{array}$ & $\begin{array}{r}1985 \\
(37) \\
\end{array}$ & $\begin{array}{r}1984 \\
(30) \\
\end{array}$ \\
\hline Leucon nasica & $\begin{array}{l}1983 \\
(269) \\
\end{array}$ & $\begin{array}{l}1981 \\
(107) \\
\end{array}$ & $\begin{array}{r}1982 \\
(96) \\
\end{array}$ & $\begin{array}{r}1984 \\
(28) \\
\end{array}$ & $\begin{array}{r}1985 \\
(18) \\
\end{array}$ & Pholoe minuta & $\begin{array}{l}1983 \\
(146) \\
\end{array}$ & $\begin{array}{r}1985 \\
(87) \\
\end{array}$ & $\begin{array}{r}1981 \\
(64) \\
\end{array}$ & $\begin{array}{r}1982 \\
(54)\end{array}$ & $\begin{array}{r}1984 \\
(48)\end{array}$ \\
\hline Mysella bidentata & $\begin{array}{l}1983 \\
(130) \\
\end{array}$ & $\begin{array}{c}1982 \\
(130) \\
\end{array}$ & $\begin{array}{l}1981 \\
(125) \\
\end{array}$ & $\begin{array}{c}1985 \\
(107) \\
\end{array}$ & $\begin{array}{r}1984 \\
(58) \\
\end{array}$ & Glycera alba & $\begin{array}{r}1983 \\
(20) \\
\end{array}$ & $\begin{array}{r}1985 \\
(18) \\
\end{array}$ & $\begin{array}{r}1981 \\
(14)\end{array}$ & $\begin{array}{r}1984 \\
(13) \\
\end{array}$ & $\begin{array}{c}1982 \\
(12)\end{array}$ \\
\hline Amphiura filiformis & $\begin{array}{r}1983 \\
(228) \\
\end{array}$ & $\begin{array}{r}1985 \\
(209) \\
\end{array}$ & $\begin{array}{r}1984 \\
(189)\end{array}$ & $\begin{array}{c}1982 \\
(150) \\
\end{array}$ & $\begin{array}{l}1981 \\
(115) \\
\end{array}$ & Lumbrineris sp. & $\begin{array}{r}1983 \\
(36) \\
\end{array}$ & $\begin{array}{r}1981 \\
(36) \\
\end{array}$ & $\begin{array}{r}1984 \\
(31) \\
\end{array}$ & $\begin{array}{r}1985 \\
(30) \\
\end{array}$ & $\begin{array}{r}1982 \\
(28) \\
\end{array}$ \\
\hline Montacuta tenella & $\begin{array}{r}1985 \\
\quad(7) \\
\end{array}$ & $\begin{array}{r}1984 \\
(6) \\
\end{array}$ & $\begin{array}{r}1983 \\
(5) \\
\end{array}$ & $\begin{array}{r}1982 \\
(3) \\
\end{array}$ & $\begin{array}{r}1981 \\
(3) \\
\end{array}$ & $\begin{array}{l}\text { Cylichna } \\
\text { cylindracea }\end{array}$ & $\begin{array}{r}1983 \\
(22) \\
\end{array}$ & $\begin{array}{r}1982 \\
(22) \\
\end{array}$ & $\begin{array}{r}1981 \\
(20) \\
\end{array}$ & $\begin{array}{r}1985 \\
(20) \\
\end{array}$ & $\begin{array}{r}1984 \\
(17) \\
\end{array}$ \\
\hline Corbula gibba & $\begin{array}{r}1983 \\
(19) \\
\end{array}$ & $\begin{array}{r}1984 \\
\quad(6) \\
\end{array}$ & $\begin{array}{r}1981 \\
\quad(4) \\
\end{array}$ & $\begin{array}{r}1985 \\
(3) \\
\end{array}$ & $\begin{array}{r}1982 \\
(2)\end{array}$ & Goniada maculata & $\begin{array}{r}1985 \\
(27) \\
\end{array}$ & $\begin{array}{r}1984 \\
(17) \\
\end{array}$ & $\begin{array}{r}1981 \\
(14) \\
\end{array}$ & $\begin{array}{r}1983 \\
(13) \\
\end{array}$ & $\begin{array}{r}1982 \\
(9)\end{array}$ \\
\hline Phoronis muelleri & $\begin{array}{r}1985 \\
(7) \\
\end{array}$ & $\begin{array}{r}1984 \\
\quad(6) \\
\end{array}$ & $\begin{array}{r}1982 \\
(5) \\
\end{array}$ & $\begin{array}{r}1981 \\
(4) \\
\end{array}$ & $\begin{array}{c}1983 \\
(0.3)\end{array}$ & Nephtys incisa & $\begin{array}{r}1983 \\
(12) \\
\end{array}$ & $\begin{array}{r}1981 \\
(12) \\
\end{array}$ & $\begin{array}{r}1985 \\
(10) \\
\end{array}$ & $\begin{array}{r}1982 \\
(8) \\
\end{array}$ & $\begin{array}{r}1984 \\
\quad(6) \\
\end{array}$ \\
\hline $\begin{array}{l}\text { Heteromastus } \\
\text { filiformis }\end{array}$ & $\begin{array}{l}1983 \\
(725) \\
\end{array}$ & $\begin{array}{l}1981 \\
(599)\end{array}$ & $\begin{array}{l}1985 \\
(673)\end{array}$ & $\begin{array}{l}1984 \\
(651)\end{array}$ & $\begin{array}{l}1982 \\
(449) \\
\end{array}$ & $\begin{array}{l}\text { Paramphinome } \\
\text { jeffreysi }\end{array}$ & $\begin{array}{r}1981 \\
(65) \\
\end{array}$ & $\begin{array}{r}1983 \\
(24) \\
\end{array}$ & $\begin{array}{c}1982 \\
(21) \\
\end{array}$ & $\begin{array}{c}1985 \\
(18) \\
\end{array}$ & $\begin{array}{r}1984 \\
\quad(17) \\
\end{array}$ \\
\hline
\end{tabular}

Among suspension feeders the ophiuroid Amphiura filiformis and the bivalve Corbula gibba showed a highly significant change $(\mathrm{p}<0.001$ ). Although the suspension-feeding $A$. filiformis had a peak density in 1983, similar to surface-deposit feeders and predators, it showed a different overall pattern, namely an increasing trend over the period. The phoronid Phoronis muelleri changed significantly ( $p<0.05)$. whereas the montacutid bivalves Mysella bidentata and Montacuta tenella did not ( $p>0.05)$.

Among subsurface-deposit feeders the polychaetes Heteromastus filiformis, Scalibregma inflatum and Paraonis gracilis and the bivalve Thyasira sarsi showed highly significant ( $p<0.001$ ) changes. The gastropod Onoba vitrea and the bivalve Thyasira equalis changed significantly $(p<0.05)$ whereas the polychaete Rhodine loveni did not ( $\mathrm{p}>0.05)$.

Among predators 2 taxa, the group Nemertini and the polychaete Pholoe minuta, showed highly significant $(p<0.001$ ) changes with a pattern similar to most surface-deposit feeders (Table 6). The polychaete Glycera alba changed significantly $(\mathrm{p}<0.05)$ with a similar pattern. The polychaetes Goniada maculata and Paramphinome jeffreysi showed a very significant change $(p<0.01)$, whereas the gastropod Cylichna cylindracea and the polychaetes Lumbrineris sp. and Nephtys incisa did not change $(p>0.05)$.

A total of 13 species out of 28 showed a highly significant $(p<0.001)$ change, and out of these 13 species 9 had highest densities in 1983. A significant 
change $(p<0.05)$ was shown by 21 out of 28 species and of these 12 had highest abundances in 1983. For 18 species the abundance in 1983 was in the group of highest abundances (Table 6). As is evident from Table 5 many of the species showing the ' 1983 peak pattern' ocurred among the 5 top species in a large proportion of the samples, and it is therefore likely that these species have induced most of the pattern observed for the totals of the functional groups.

Indicated in Table 5 are approximate life spans based primarily on information from Buchanan \& Warwick (1974) and Wildish \& Peer (1983). Most of the species showing the common pattern of co-variation, and most other dominants as well, have life spans around 2 yr and less.

Concurrently with the sampling of fauna, samples were taken for water content, organic content and redox potential in the surface sediment. Area means for the 2 former variables and results of testing for differences between years (1983-85) are given in Table 7 . Loss on ignition of organics showed significant changes as would have been predicted from the faunal changes. The loss decreased between 1983 and 1984 when the fauna decreased. As the fauna was not removed from the samples for organic content it is not known whether measured changes in this variable were a cause or an effect of the noted changes in faunal density. However, benthic biomass showed only small insignificant differences during the same period (Josefson 1986b). The redox potential showed a significant decrease between 1984 and 1985 in the top $7 \mathrm{~cm}$ of the sediment over the area (Josefson 1986b). This is also to be expected from the other changes. Water content changed significantly in the same way as the organic content (Table 7).

\section{DISCUSSION}

The present data show that general changes in the benthic dynamics have taken place in this area of the Skagerrak during a $5 \mathrm{yr}$ period. Much of this variation apparently is attributed to short-lived polychaetes and cumaceans. The large-scale character of the changes makes biological factors such as competition or predation unlikely causes of this change. Both dominant detritivores and predators differ between stations, and yet basically the same pattern of co-variance is shown between species. The underlying factors are therefore likely to be extrinsic to the local communities. There does not seem to be any substantial differences either in magnitude or in the pattern of the variations in the 2 reproductive categories (Fig. 4). This result therefore suggests that the main factor operated on the bottom.

Additional data from the present area demonstrating co-variation between study sites are provided by Josef-
Table 7 . Investigation area means for the sediment variables water content and loss on ignition based on data from 12 stations in the years 1983-85. See Table 2 for further information

\begin{tabular}{|ccccc|}
\hline Variable & Sign & 1985 & 1983 & 1984 \\
\hline $\begin{array}{l}\text { Water content }(\%) \\
0-2 \mathrm{~cm}\end{array}$ &. & $\underline{58.0}$ & $\frac{57.2}{5}$ & 56.7 \\
$\begin{array}{l}2-6 \mathrm{~cm} \\
\text { Loss on ignition (\%) } \\
0-2 \mathrm{~cm}\end{array}$ & $\ldots$ & $\underline{52.3}$ & $\frac{7.46}{52.6}$ & $\underline{50.7}$ \\
$2-6 \mathrm{~cm}$ & $\ldots$ & $\underline{7.08}$ & 7.15 & $\underline{5.10}$ \\
\hline
\end{tabular}

son (1986b). He found a significant ( $p<0.05$ ) positive correlation between total abundances at Stns 8 and 9 (Fig. 1) over the period 1973-85. These 2 stations are situated at different depths, 300 and $100 \mathrm{~m}$ respectively, and more than $30 \mathrm{~km}$ apart, and furthermore have to a large extent different dominating species.

Very few previous studies exist that demonstrate synchronization of fluctuations in abundance over large areas. Ziegelmeier $(1964,1978)$ showed co-variation in abundance of the dominating species Spiophanes bombyx and Tellina fabula over a 24 yr period in the eastern German Bight. A minimum of the latter species and maxima of the former one were attributed to cold winters. Andersin et al. (1978) in a study from the Bothnian Bay found large scale oscillations in abundance of the dominant amphipod Pontoporeia affinis over a $20 \mathrm{yr}$ period. Gray \& Christie (1983) related these oscillations to large-scale changes in temperature and salinity.

While it is now well documented how variations in temperature and salinity may have dramatic effects in shallow water systems it is not equally obvious how relatively small changes in these variables may induce variations in abundance in deeper water. Nevertheless hyptheses on the causes of changes in sub-tidal benthos have often involved temperature (e.g. Thorson 1950, Buchanan et al. 1978), while long-term studies relating benthic dynamics to sedimentation are few (but see Valderhaug \& Gray 1984, Buchanan \& Moore 1986). The former authors did not find any effect related with seasonal sedimentation of chlorophyll at $32 \mathrm{~m}$ depth in the Oslofjord. They suggested control by infaunal predators as a cause of the faunal stability in abundances.

There are several possible reasons for the variability observed in the present area. One is that the timing of the larval settlement differs between years. That is, the time of recruitment to the bottom and into the sieve differs between the years. Another reason could be that early growth rates differ between the years. In both cases the observed variations do not represent changes 
in absolute abundances, but still these changes suggest general action of some extrinsic factor. Although several factors may influence settling time and growth, temperature is one. As mentioned earlier, however, temperature conditions were very similar during the actual years. Although 1983, which preceeded the minimum in May 1984, was the coldest year, 1982 before the maximum in May 1983 was not the warmest year. This possibly rules out this factor as one of major influence.

Another possibility is that changes in the sediment due to erosion have affected the benthos. The decrease in organics and water content in May 1984 took place at nearly all 12 stations, and in fact, the greatest relative change in organics took place at the deepest station (Stn 8) at $300 \mathrm{~m}$ depth, where the decrease was $40 \%$ compared with the average $17 \%$. At the 2 most exposed stations, Stn 1 at $10 \mathrm{~m}$ and $\operatorname{Stn} 7$ at $49 \mathrm{~m}$ water depth, no changes were observed. Therefore, erosion does not seem to be a likely explanation of the sediment changes.

On the other hand a production-related factor may be important, such as sedimentation of primary production. If food is a limiting resource, variations in organic input may induce variations in number of individuals as well as in growth rates of the established ones (Pearson \& Rosenberg 1978, Dauer \& Conner 1980). Variations in abundance are likely to be evident particularly in short-lived species as there is little 'hang over' from older generations. As shown in Table 5, most of the species showing significant variations have a relatively short life span.

The observation that the general change occurred also at greater depths is not surprising as it is known that food pulses may rapidly reach great depths (e.g. Billett et al. 1983, Wassmann 1983, Davies \& Payne 1984). Recent measurements of plant pigments from this area do indeed suggest that considerable amounts of chlorophyll a reached the bottom in May at most of the present stations (Josefson unpubl.). A response among deposit feeders is in accordance with some recent work suggesting that deposit feeders may also directly utilize the chlorophyll from plankton blooms (Christensen \& Kanneworff 1985).

Interestingly the maximum content of chlorophyll a during the spring blooms at Stn 11 (Odd Lindahl pers. comm.) showed a similar pattern to total abundance with the highest value in February/March 1983. If this was a general phenomenon, and if the blooms reached the bottoms as rapidly as reported elsewhere (refs above), it is perfectly possible that somatic growth was affected the same year and caused changes in sieve recruitment. The time between sampling and date of sedimentation may have been ca 2 mo.

The high degree of co-variation in predatory species may seem contradictory to the view that sedimentation is the important factor. However, Pholoe minuta constitutes a great part of this category, and it cannot be ruled out that its variations are influenced by the variations of Prionospio malmgreni. Both species show a similar pattern and it is known that $P$. minuta may predate on P. malmgreni if it is available (Pleijel 1983). The frequency of sampling used here does not allow the detection of possible time lags in population dynamics between predator and prey. It is however a possibility that a good settlement of $P$. malmgreni in late summer, or autumn, allowed an enhanced survival of young $P$. minuta already present from the spring before.

In spite of the significant fluctuations, the dominance structure within categories seemed largely unaltered. This would be the result if co-variation instead of exclusion occurred between species, that is if most of the actual species responded similarly to changes in for instance organic input. The species most responsible for the common pattern observed here also have widely different recruitment periods (Table 5; see Buchanan et al. 1986, Josefson 1986a), suggesting a synchronisation of the variations also within stations.

A similar result was obtained by Buchanan et al. (1986) who presented strong indications of resource limitation in subtidal soft-sediment benthos. Studying a $55 \mathrm{~m}$ deep locality off the Northumberland (U. K.) coast over a 8 yr period, they found a clear pattern of abundance with alternating high and low densities each year. This pattern was similar between species in spite of different recruitment periods.

In conclusion, the reasoning above favours the hypothesis that some common factor(s) has been important that affects either of, or a combination of, settlement, early growth and survival on the bottom. Although other factors such as temperature cannot be eliminated, variations in sedimentation of organic matter seems the most probable underlying cause of the observed large-scale variability in dynamics. This issue certainly warrants further examination and testing.

Acknowledgements. Thanks go to W. A. Crowe for reading the manuscript, to S. Agrenius, S. Carlberg, F. Gröndahl and S. Mattson for sample processing and help with the field work. The paper benefited from criticism by 3 anonymous reviewers. Work was done at the Kristineberg Marine Biological Station which is hereby acknowledged. Financial support was given by the Swedish Environment Protection Board and the data used in this paper were collected within the Swedish Environmental Monitoring Program, PMK.

\section{LITERATURE CITED}

Andersin, A.-B., Lassig, J., Parkkonen, L., Sandler, H. (1978). Long-term fluctuations of the soft bottom macrotauna in the deep areas of the Gulf of Bothnia 1954-1974: with 
special reference to Pontoporeia affinis Lindstrom (Amphipoda). Finn. Mar. Res. 244: 137-144

Beukema, J. J., Bruin, W. de, Jansen, J. J. M. (1978). Biomass and species richness of the macrobenthic animals living on the tidal flats of the Dutch Wadden Sea: long-term changes during a period with mild winters. Neth. J. Sea Res. 12: 52-77

Billett, D. S. M., Lampitt, R. S., Rice, A. L., Mantoura, R. F. C. (1983). Seasonal sedimentation of phytoplankton to the deep-sea benthos. Nature, Lond. 302: 520-522

Buchanan, J. B., Brachi, R., Christie, G., Moore, J. J. (1986). An analysis of a stable period in the Northumberland benthic fauna - 1973-80. J. mar. biol. Ass. U. K. 66: 659-670

Buchanan, J. B., Moore, J. J. (1986). A broad review of variability and persistance in the Northumberland benthic fauna - 1971-85. J. mar. biol. Ass. U. K. 66: 641-657

Buchanan, J. B., Sheader, M., Kingston, P. F. (1978). Sources of variability in the benthic macrofauna off the south Northumberland coast, 1971-1976. J. mar. biol. Ass. U. K. 58: 191-209

Buchanan, J. B., Warwick, R. M. (1974). An estimate of the benthic macrofaunal production in the offshore mud of the Northumberland coast. J. mar. biol. Ass. U. K. 54: 197-222

Christensen, H., Kanneworff, E. (1985). Sedimenting phytoplankton as major food source for suspension and deposit feeders in the Oresund. Ophelia 24: 223-244

Coull, B. C. (1985). Long-term variability of estuarine meiobenthos: an 11 year study. Mar. Ecol. Prog. Ser. 24: 205-218

Coull, B. C., Dudley, B. W (1985). Dynamics of meiobenthic copepod populations: a long-term study (1973-1983). Mar. Ecol. Prog. Ser. 24: 219-229

Dauer, D. M., Conner, W. G. (1980). Effects of moderate sewage input on benthic poolyphaete populations. Estuar. coast. mar. Sci. 10: 335-346

Davies, J. M., Payne, R. (1984). Supply of organic matter to the sediment in the northern North Sea during a spring phytoplankton bloom. Mar. Biol. 78: 315-324

Gaston, G. R. (1985). Effects of hypoxia on macrobenthos of the inner shelf off Cameron. Louisiana. Estuar coast. Shelf Sci. 20: 603-613

Gray, J. S., Christie, H. (1983). Predicting long-term changes in marine benthic communities. Mar. Ecol. Prog. Ser 13: $87-94$

Grossman, G. D., Moyle, P. B., Whitaker, J. O., Jr. (1982). Stochasticity in structural and functional characteristics of an Indiana strearn fish assemblage: a test of community theory. Am. Nat. 120: 423-454

Josefson, A. B. (1981). Persistence and structure of two deep macrobenthic communities in the Skagerrak (west coast of Sweden). J. exp. mar. Biol. Ecol. 50: 63-97

Josefson, A. B. (1982). Regulation of population size, growth, and production of a deposit-feeding bivalve: a long-term field study of three deep-water populations off the Swedish west coast. J. exp. mar. Biol. Ecol. 59: 125-150

Josefson, A. B. (1985). Distribution of diversity and functional groups of marine benthic infauna in the Skagerrak (eastem North Sea) - Can larval availability affect diversity? Sarsia 70: 229-249
Josefson, A. B. (1986a). Temporal heterogeneity in deepwater soft-sediment benthos - an attempt to reveal temporal structure. Estuar. coast. Shelf Sci. 23: 147-169

Josefson, A. B. (1986b). Overvakning av mjukbottenfauna längs Sveriges västkust. Naturvårdsverket Rapport 3247 : 1-72. (Swedish; English summary)

Josefson, A. B., Smith, S. (1984). Changes of benthos-biomass in the Skagerrak-Kattegat during the 1970-ies: a result of chance events, climatic changes or eutrophication? Medd. Havsfiskelab. Lysekil 292: 111-121. (Swedish; English summary)

Pearson, T. H., Rosenberg, R. (1978). Macrobenthic succession in relation to organic enrichment and pollution of the marine environment. Oceanogr. Mar. Biol. A. Rev. 16: 229-311

Pleijel, F. (1983). On feeding of Pholoe minuta (Fabricius, 1780) (Polychaeta: Sigalionidae). Sarsia 68: 21-23

Sanders, H. L. (1968). Marine benthic diversity: a comparative study. Am. Nat. 102: 243-282

SAS Institute Inc. (1982). SAS user's guide: statistics. 1982 edn. SAS Institute Inc., Cary, North Carolina

Siegel, S. (1956). Nonparametric statistics for the behavioral sciences. McGraw-Hill, London

Sokal, R. R., Rohlf, F. J. (1969). Biometry, 1st edn. W. H. Freeman \& Co., San Francisco

Sokal, R. R., Rohlf, F. J. (1981). Biometry, 2nd edn. W. H. Freeman \& Co., San Francisco

Stull, J. K., Haydock, C. I., Smith, R. W., Montagne, D. E. (1986). Long-term changes in the benthic community on the coastal shelf of Palos Verdes, Southern California. Mar. Biol. 91: 539-551

Svansson, A. (1975). Physical and chemical oceanography of the Skagerrak and the Kattegat. I. Open sea conditions. Fish. Bd Sweden Rep. No. 1: 1-88

Thorson, G. (1950). Reproductive and larval ecology of marine botton invertebrates. Biol. Rev. 25: 1-45

Valderhaug, V. A., Gray, J. S. (1984). Stable macrofauna community structure despite fluctuating food supply in subtidal soft sediments of Oslofjord, Norway, Mar. Biol. 82: $307-322$

Wassmann, P. (1983). Sedimentation of organic and inorganic particulate material in Lindåspollene, a stratified, landlocked fjord in western Norway. Mar. Ecol. Prog. Ser. 13: $237-248$

Wildish, D. J., Peer, D. (1983). Tidal current speed and production of benthic macrofauna in the lower Bay of Fundy. Can J. Fish. Aquat. Sci. 40 (Suppl. 1): 309-321

Ziegelmeier, E. (1963). Das Macrobenthos im Ostteil der Deutschen Bucht nach qualitativen und quantitativen Bodengreiferuntersuchungen in der Zeit von 1949-1960. Veröff. Inst. Meeresforsch. Bremerh., Sonderband: Drittes meeresbiolog. Symposium: 101-114

Ziegelmeier, E. (1964). Einwirkungen des kalten Winters 1962/63 auf das Makrobenthos im Ostteil der Deutschen Bucht. Helgoländer wiss. Meeresunters. 10: 276-282

Ziegelmeier, E. (1978). Macrobenthos investigations in the eastern part of the German Bight from 1950 to 1974. Rapp. P.-v. Réun. Cons. int. Explor. Mer 172: 432-444 